\title{
Modulation of Neuronal Signal Transduction Systems by Extracellular ATP
}

\author{
${ }^{*} \nmid Y$. H. Ehrlich, $¥$ R. M. Snider, *E. Kornecki, *§M. G. Garfield, and *R. H. Lenox \\ The Neuroscience Research Unit, ${ }^{*}$ Department of Psychiatry, Departments of $\dagger$ Biochemistry and \$Pharmacology, \\ University of Vermont, Burlington, Vermont; and $\ddagger$ The Mental Health Research Institute, \\ University of Michigan, Ann Arbor, Michigan. U.S.A.
}

\begin{abstract}
The secretion of ATP by stimulated nerves is well documented. Following repetitive stimulation, extracellular ATP at the synapse can accumulate to levels estimated to be well over $100 \mu M$. The present study examined the effects of extracellular ATP in the concentration range of $0.1-1.0 \mathrm{~m} M$ on second-messenger-generating systems in cultured neural cells of the clones NG108-15 and N1E-115. Cells in a medium mimicking the physiological extracellular environment were used to measure ${ }^{45} \mathrm{Ca}^{2+}$ uptake, changes in free intracellular $\mathrm{Ca}^{2+}$ levels by the probes aequorin and Quin-2, de novo generation of cyclic GMP and cyclic AMP from intracellular GTP and ATP pools prelabeled with $\left[{ }^{3} \mathrm{H}\right]$ guanosine and $\left[{ }^{3} \mathrm{H}\right]$ adenine, respectively, and phosphoinositide metabolism in cells preloaded with $\left[{ }^{3} \mathrm{H}\right]$ inositol and assayed in the presence of $\mathrm{LiCl}$. Extracellular ATP induced a concentration-dependent increase of ${ }^{45} \mathrm{Ca}^{2+}$ uptake by intact cells, which was additive with the uptake induced by $\mathrm{K}^{+}$depolarization. The increased uptake involved elevation of intracellular free $\mathrm{Ca}^{2+}$ ions, evidenced by measuring aequorin and Quin-2 signals. At the same concentration range $(0.1-1.0 \mathrm{mM})$, extracellular ATP
\end{abstract}

induced an increase in $\left[{ }^{3} \mathrm{H}\right]$ cyclic GMP formation, and a decrease in prostaglandin $\mathrm{E}_{1}$-stimulated $\left[{ }^{3} \mathrm{H}\right]$ cyclic AMP generation. In addition, extracellular ATP $(1 \mathrm{mM})$ caused a large (15-fold) increase in $\left[{ }^{3} \mathrm{H}\right]$ inositol phosphates accumulation, and this effect was blocked by including $\mathrm{La}^{3+}$ ions in the assay medium. In parallel experiments, we found in NG108-15 cells surface protein phosphorylation activity that had an apparent $K_{\mathrm{m}}$ for extracellular ATP at the same concentration required to produce half-maximal effects on $\mathrm{Ca}^{2+}$ uptake. Extracellular ATP at concentrations that can be produced in the synaptic cleft by repetitive stimulation but not during routine transmission can thus initiate a unique chain of events, which may play a role in the induction of long-term adaptive changes in neuronal function. Key Words: Extracellular ATP-Calcium uptake-Calcium transients-Adenylate cyclase-Guanylate cyclasePhosphoinositide metabolism-Ecto-protein kinase. Ehrlich Y.H. et al. Modulation of neuronal signal transduction systems by extracellular ATP. $J$. Neurochem. 50, 295-301 (1988).
ATP has been detected in the extracellular environment of various tissues, but only three cell types (neurons, adrenomedullary cells, and platelets) are known to store ATP within secretory vesicles and release it by exocytosis on stimulation (Gordon, 1986). The close association between neuronal activation and ATP secretion indicates that extracellular ATP may exert feedback control over the activity of the secreting nerve terminals, as well as a signal that is transmitted to target cells. The first study suggesting that ATP plays a role in neurotransmission was reported by Holton and Holton (1954). Subsequent studies have provided evidence that ATP is stored and released as a cotransmitter from cholinergic and adrenergic nerves in the peripheral nervous system (Silinsky and Hubbard, 1973; Silinsky, 1975: Winkler, 1976; Zimmerman, 1978; Stone, 1981: Castel et al., 1984), and recently the release of ATP from cholinergic nerve endings isolated from the CNS has been demonstrated by Richardson and Brown (1987). In addition, Burnstock (1972, 1975. 1981) has reported findings consistent with the existence of purinergic nerves that release ATP as a principal transmitter.
Received May 14, 1987; revised manuscript received August 3, 1987; accepted August 6, 1987.

Address correspondence and reprint requests to Dr. Y. H. Ehrlich at Department of Psychiatry, Medical Alumni Building, University of Vermont, Burlington, VT 05405, U.S.A
Abbreviations used: DMEM. Dulbecco's modified Eagle medium; HEPES, $N$-2-hydroxyethylpiperazine- $N$-2-ethanesulfonic acid; IP, inositol phosphates: LTP, long-term potentiation: PGE $_{1}$, prostaglandin $E_{1}$ : TCA. trichloroacetic acid 
ATP secreted by nerve terminals is rapidly hydrolyzed by ectonucleotidases to adenosine, which is a potent neuroregulator (Daly et al., 1983; Williams, 1987). It has been difficult to determine, therefore, whether ATP itself exerts direct effects on neuronal function. The finding of transmission systems in which ATP is more effective than adenosine has led to the classification of two types of responses: those mediated by $P_{1}$ receptors are most sensitive to adenosine, and those mediated by $P_{2}$-purinoreceptors are elicited by ATP and its unhydrolyzable analogs (Burnstock, 1981; Williams, 1987). Furthermore, certain modulatory effects of extracellular ATP were found to require native, hydrolyzable ATP and thus do not appear to involve $P_{1}$ - or $P_{2}$-purinergic receptors. Such modulation has been observed at presynaptic sites (Silinsky and Ginsborg, 1983) as well as postsynaptically (Hume and Honig, 1986). The requirement of native ATP for the modulation of certain synaptic functions may be related to the finding of ectoprotein kinase(s) that phosphorylate proteins at the surface of neural cells, and use extracellular ATP as a cosubstrate (Ehrlich et al., 1986a,b).

One of the unique features of neuronal systems is synaptic plasticity. The involvement of ATP secreted by neurons in the process that initiates the production of long-term alterations in synaptic function has not been investigated yet. Such involvement is suggested by recent findings on the mechanisms underlying the development of long-term potentiation (LTP). LTP is initiated by repetitive stimulation delivered at high frequency in precise intervals (Teyler and Discenna, 1984; Lynch and Baudry, 1984). One of the consequences of such repetitive stimulation would be the accumulation of extracellular ATP at the synaptic cleft to levels far greater than those obtained during routine transmission (Silinsky, 1975, 1984). In the present study we have utilized intact, cultured neural cells to determine the effects of extracellular ATP on signal transduction systems implicated in the initiation of LTP.

\section{EXPERIMENTAL PROCEDURES}

\section{Cell cultures}

Neuroblastoma $\times$ glioma hybrid cells (clone NG108-15) were obtained from Dr. M. Nirenberg (NIH) and grown in Dulbecco's modified Eagle's medium (DMEM) supplemented with $0.1 \mathrm{~m} M$ hypoxanthine, $1 \mu M$ aminopterin, 16 $\mu M$ thymidine (HAT), and $5 \%$ fetal bovine serum. For routine experiments of this study, cells (passages 20-36) were grown in $75-\mathrm{cm}^{2}$ tissue culture flasks in an atmosphere of $10 \% \mathrm{CO}_{2} / 90 \%$ humidified air. When approaching confluency and during maintenance thereafter, the medium was changed every day. Neuroblastoma cells of clone N1E-115 (passage 10-16) were cultured in DMEM supplemented with $10 \%$ fetal bovine serum, as previously described by Snider and Richelson (1984). Cells of both clones were found negative for mycoplasma (PPLO) by periodic bacteriological tests.

\section{Calcium uptake}

NG108-15 cells were harvested between 4 and 6 days after reaching confluency by gentle agitation of the flasks, and washed twice in "incubation medium" containing 145 $\mathrm{m} M \mathrm{NaCl}, 6 \mathrm{~m} M \mathrm{KCl}, 0.8 \mathrm{~m} M \mathrm{MgCl}_{2}, 1.8 \mathrm{~m} M \mathrm{CaCl}_{2}, 20$ $\mathrm{m} M$ glucose, and $25 \mathrm{~m} M N$-2-hydroxyethylpiperazine- $N^{\prime}-$ 2-ethanesulfonic acid (HEPES) (pH 7.4). After counting and viability determination, aliquots containing $1-5 \times 10^{5}$ cells $/ 50 \mu$ l were transferred to $10 \times 75 \mathrm{~mm}$ glass tubes that were placed in a shaking water bath $\left(37^{\circ} \mathrm{C}\right)$ and contained the test reagents and $1 \mu \mathrm{Ci} /$ tube of ${ }^{45} \mathrm{CaCl}_{2}$ (ICN Radiochemicals, $25 \mathrm{Ci} / \mathrm{g} \mathrm{Ca}$ ) in incubation medium. The final assay volume was $100 \mu \mathrm{l}$. When reactions were carried out under depolarizing conditions, the medium containing ${ }^{45} \mathrm{CaCl}_{2}$ (and test reagents) was adjusted such that after cell addition the final concentrations of $\mathrm{NaCl}$ and $\mathrm{KCl}$ were $95 \mathrm{mM}$ and $56 \mathrm{mM}$, respectively. The reactions were initiated by cell addition and terminated by cell collection on Whatman GFC glass fiber filters, using a Brandel Cell Harvester model M24. Following three washes within $<1 \mathrm{~min}$ with ice-cold buffer ( $145 \mathrm{~m} M \mathrm{NaCl}, 7 \mathrm{~m} M \mathrm{KCl}, 0.8 \mathrm{~m} M \mathrm{MgCl}_{2}$, $1.8 \mathrm{mM} \mathrm{CaCl} 2,50 \mathrm{mM}$ Tris-HCl, $\mathrm{pH} 7.0$ ) the filters were dried and subjected to liquid scintillation counting.

\section{Measurements of $\left[\mathrm{Ca}^{2+}\right]_{1}$}

Chemiluminescence was measured using the instrument PICA (Chrono-Log, PA, U.S.A.) set at low stirring (200 rpm) with NG108-15 cells preloaded with the probe aequorin, using the procedure of Johnson et al. (1985) as modified by Kornecki et al. (1987). In brief, NG 108-15 cells were harvested as described above and incubated with $200 \mu \mathrm{g} / \mathrm{ml}$ aequorin (purchased from Dr. J. Blinks, Rochester, MN, U.S.A.) for $1 \mathrm{~h}$ at $4^{\circ} \mathrm{C}$ in the presence of ATP (5 $\mathrm{m} M)$ and EGTA $(10 \mathrm{mM})$. After centrifugation and washings the cells were recalcified and brought slowly to $22^{\circ} \mathrm{C}$. Cell suspensions $\left(1.1 \mathrm{ml}\right.$ containing $10^{6}$ cells) were placed in the PICA cuvettes and test reagents injected through a septum.

Fluorimetric quantitation of $\left[\mathrm{Ca}^{2+}\right]_{\mathrm{i}}$ in intact cells was carried out by the procedure of Tsien et al. (1982). In brief, $1 \times 10^{6} / \mathrm{ml} \mathrm{N} 1 \mathrm{E}-115$ cells were loaded with $20-50 \mu M$ Quin-2-AM (Calbiochem) at $37^{\circ} \mathrm{C}$ for $30 \mathrm{~min}$ in a medium containing $142 \mathrm{~m} M \mathrm{NaCl}, 5.6 \mathrm{mM} \mathrm{KCl}, 1.0 \mathrm{mM} \mathrm{MgCl}_{2}$, $2.2 \mathrm{mMCaCl}$, $3.6 \mathrm{~m} M \mathrm{NaHCO}_{3}, 5.6 \mathrm{~m} M$ D-glucose, and $30 \mathrm{~m} M$ HEPES (pH 7.4; PSS medium). After dilution to approximately $3 \times 10^{5} / \mathrm{ml}$ the cells were incubated for an additional $15 \mathrm{~min}$ at $37^{\circ} \mathrm{C}$ and then centrifuged, resuspended in fresh medium ( $10^{6}$ cells $\left./ \mathrm{ml}\right)$, and kept at room temperature until use. Immediately before fluorescence recording, $1 \mathrm{ml}$ of this cell suspension was centrifuged and resuspended in $1 \mathrm{ml}$ of fresh PSS, placed in the fluorimeter (Amino-Bowman) at $37^{\circ} \mathrm{C}$, and continuously stirred. The excitation and emission wavelengths used were $339 \pm 4 \mathrm{~nm}$ and $490 \pm 10 \mathrm{~nm}$, respectively. Values of $\left[\mathrm{Ca}^{2+}\right]_{i}$ were determined as described by Tsien et al. (1982) and Arslan et al. (1985).

\section{[ ${ }^{3} \mathrm{H}$ Cyclic GMP formation}

The use of intact NIE-115 cells and assaying for relative changes in $\left[{ }^{3} \mathrm{H}\right]$ cyclic GMP are described in detail by Snider et al. (1984). In brief, the cells after growing to confluency were harvested, labeled with $\left.{ }^{3} \mathrm{H}\right]$ guanosine (Amersham, 25 $\mathrm{Ci} / \mathrm{mmol})$, and the stimulated formation of $\left[{ }^{3} \mathrm{H}\right]$ cyclic GMP was quantified by scintillation counting using $\left[{ }^{14} \mathrm{C}\right]-$ 
cyclic GMP as internal standard to correct for recovery of chromatographically separated $\left[{ }^{3} \mathrm{H}\right]$ cyclic GMP.

\section{$\left[{ }^{3} \mathrm{H}\right]$ Cyclic AMP accumulation}

The procedures detailed by Lenox et al. (1985) were modified for use with NG108-15 cells. Cells were harvested, washed, and resuspended in DMEM medium (without serum or HAT). One milliliter containing $20 \times 10^{6}$ cells was supplemented with $20 \mu \mathrm{Ci}$ of $\left[{ }^{3} \mathrm{H}\right]$ adenine (New England Nuclear, $20 \mathrm{Ci} / \mathrm{mmol}$ ) and shaken in the incubator for $60 \mathrm{~min}$. After two washes, the cells were suspended in the same incubation medium described above for the measurement of ${ }^{45} \mathrm{Ca}^{2+}$ uptake. The reactions ( $100 \mu$ l final volume) were initiated by adding cells $\left(5 \times 10^{5} /\right.$ assay) to tubes containing the medium, test reagents, and the phosphodiesterase inhibitor Ro 20-1724 in a final concentration of $1 \mathrm{~m} M$. Termination of the reactions by heating $\left(90^{\circ} \mathrm{C}, 10\right.$ $\mathrm{min}$ ) and isolation of $\left[{ }^{3} \mathrm{H}\right]$ cyclic AMP by sequential chromatography on Dowex $50 \mathrm{H}^{+}$and alumina columns was carried out as described previously by Lenox et al. (1985).

\section{$\left.{ }^{3} \mathrm{H}\right]$ Inositol phosphates $\left(\left.\right|^{3} \mathrm{H}\right][\mathrm{P})$ release}

myo- $\left[2-{ }^{3} \mathrm{H}\right]$ Inositol was passed over a Dowex-1 column (formate form) to remove any acidic contaminants before use. Release of IP in N1E-115 cells prelabeled with $\left[{ }^{3} \mathrm{H}\right]$ inositol was determined by a batch-adsorption procedure on Dowex-1 (formate), essentially as described by Fisher et al. (1984). In brief, freshly isolated cells were centrifuged and resuspended $\left(10^{6} / \mathrm{ml}\right)$ in PSS medium containing 5-10 $\mu \mathrm{Ci} / \mathrm{ml}$ of $m y o-\left[2-{ }^{3} \mathrm{H}\right]$ inositol (American Radiolabeled Chemicals, St. Louis, MO, U.S.A., $14 \mathrm{Ci} / \mathrm{mmol}$ ) and incubated at $37^{\circ} \mathrm{C}$ for $60 \mathrm{~min}$. Following the preincubation period, $450-\mu \mathrm{l}$ portions of the cell suspension $\left(3 \times 10^{5}\right.$ cells $)$ were added to tubes containing $50 \mu \mathrm{l}$ of medium and test reagents and the reaction allowed to proceed for an additional $30 \mathrm{~min}$ in the presence of $\mathrm{Li}^{+}(10 \mathrm{mM})$. The reaction was stopped by the addition of $1.5 \mathrm{ml}$ of chloroform $/$ methanol $(1: 2 \mathrm{vol} / \mathrm{vol})$ and the tubes stored on ice for $15-60$ min. After addition of $1 \mathrm{ml}$ of chloroform and $0.5 \mathrm{ml}$ of water, the tubes were vortex-mixed vigorously and the phases separated by centrifugation. A portion $(1.4 \mathrm{ml})$ of the upper phase (aqueous) was removed and heated at $56^{\circ} \mathrm{C}$ for $15 \mathrm{~min}$ to remove traces of chloroform, brought to 3.0 $\mathrm{ml}$ with water, and $0.5 \mathrm{ml}$ of a $50 \%$ (wt/vol) slurry of Dowex-1 (formate) was added. Following vigorous vortexmixing and centrifugation, the supernatant layer was aspirated and the resin washed five times with $2.5 \mathrm{ml}$ of $5 \mathrm{mM}$ myo-inositol. Labeled IP were eluted from the resin with 1 $\mathrm{ml}$ of $1 M$ ammonium formate/ $0.1 \mathrm{M}$ formic acid of which a $0.85-\mathrm{ml}$ portion was counted.

\section{Protein phosphorylation assays}

The incorporation of ${ }^{32} \mathrm{P}$-phosphate into the proteins of cells incubated with $\left[\gamma-{ }^{32} \mathrm{P}\right] \mathrm{ATP}$ added to the extracellular medium was measured by the trichloroacetic acid (TCA) precipitation procedure, essentially as described by Mastro and Rozengurt (1976). NG108-15 cells were harvested. washed, and resuspended as detailed above for the assay of ${ }^{45} \mathrm{Ca}^{2+}$ uptake and using the same incubation medium. The reaction (final volume of $100 \mu \mathrm{l}$ ) was initiated by adding $\left[\gamma-{ }^{32} \mathrm{P}\right]$ ATP (ICN Radiochemicals, $4,500 \mathrm{Ci} / \mathrm{mmol}$ ) to cells at $37^{\circ} \mathrm{C}$. After a $10-$ min incubation in a shaking water bath, the reaction was terminated by adding $1 \mathrm{ml}$ of $10 \%$ ice-cold TCA in $1 M \mathrm{H}_{3} \mathrm{PO}_{4}$. TCA-insoluble material was isolated by centrifugation, dissolved in $0.4 \mathrm{ml}$ of cold $0.4 M \mathrm{NaOH}$. reprecipitated with $5 \mathrm{ml}$ of $5 \%$ TCA $/ 0.5 M \mathrm{H}_{3} \mathrm{PO}_{4}$, washed twice, and subjected to scintillation counting. Under these assay conditions incorporation was found to be linearly proportional to cell concentration $\left(1-10 \times 10^{5} / \mathrm{ml}\right.$; Ehrlich et al., 1986b). With ATP added to make an initial concentration of $100 \mu M$, product formation was linear with time for at least $20 \mathrm{~min}$, and $>80 \%$ of the incorporated ${ }^{32} \mathrm{P}$ phosphate was found to be bound to protein in a phosphomonoester linkage, as expected from products of protein kinase activity (Ehrlich, 1984).

\section{RESULTS}

Depolarization of neurons induced by increasing extracellular $\mathrm{KCl}$ concentration causes an influx of $\mathrm{Ca}^{2+}$ ions into the cells. Table 1 demonstrates that in cultured neural cells of the hybrid clone NG108-15 (Nirenberg et al., 1983; Hamprecht et al., 1985) there is about twofold increase in $\mathrm{Ca}^{2+}$ uptake when the cells are stimulated with $50 \mathrm{mM} \mathrm{KCl}$. It should be emphasized that these measurements were conducted in a buffer mimicking a physiological extracellular environment, and using a calcium concentration (1.8 $\mathrm{m} M$ ) present in the normal growth medium. A trace amount $\left(1 \mu \mathrm{Ci}\right.$ /assay) of ${ }^{45} \mathrm{CaCl}_{2}$ was added to the cells simultaneously with the stimulating agents. Using the same assay conditions, we have measured the effects of adding increasing concentrations of ATP to the extracellular medium on ${ }^{45} \mathrm{Ca}^{2+}$ uptake in NG108-15 cells. Beginning with ATP added to make a final concentration of $100 \mu M$, we observed a significant ( $\mathrm{p}<0.05$ by Student's $t$ test) and reproducible increase of ${ }^{45} \mathrm{Ca}^{2+}$ uptake. Maximal effects (about fivefold over basal conditions) were obtained on addition of $1 \mathrm{~m} M$ ATP to the extracellular medium (Table 1), and higher ATP concentrations did not produce a further increase. The mean ATP concentration needed to produce half-maximal increase of ${ }^{45} \mathrm{Ca}^{2+}$ uptake in NG108-15 cells was $520 \mu M$. When added at these concentrations, adenosine did not

TABLE 1. Effects of extracellular ATP on " $\mathrm{Ca}^{2+}$ uptake

\begin{tabular}{|c|c|c|}
\hline Incubation conditions & ${ }^{45} \mathrm{Ca}^{2+}$ uptake & $\begin{array}{c}\text { Increase above } \\
\text { basal }(\%)\end{array}$ \\
\hline $\begin{array}{l}\text { Basal }\left(6 \mathrm{mM} \mathrm{K}^{+}\right) \\
56 \mathrm{~m} M \mathrm{~K}^{+}\end{array}$ & $\begin{array}{r}8,820 \pm 350 \\
16,830 \pm 460\end{array}$ & $\overline{91}$ \\
\hline $\begin{array}{l}0.1 \mathrm{~m} M \text { ATP } \\
0.1 \mathrm{~m} M \text { ATP in } 56 \mathrm{~m} M \mathrm{~K}^{+}\end{array}$ & $\begin{array}{l}12.220 \pm 1.410 \\
20.390 \pm 400\end{array}$ & $\begin{array}{r}38 \\
131\end{array}$ \\
\hline $\begin{array}{l}1.0 \mathrm{~m} M \text { ATP } \\
\text { 1.0 mMATP in } 56 \mathrm{~m} M \mathrm{~K}^{+}\end{array}$ & $\begin{array}{l}50,920 \pm 1.590 \\
56.990 \pm 2.660\end{array}$ & $\begin{array}{l}477 \\
545\end{array}$ \\
\hline
\end{tabular}

NG108-15 cells were stimulated by raising the $\mathrm{KCl}$ concentration in the medium to $50 \mathrm{mM}$ above basal conditions (by substituting for an equivalent amount of $\mathrm{NaCl}$ ). ${ }^{4} \mathrm{Ca}^{2+}$ uptake was measured as described under Experimental Procedures, with and without addition of the indicated ATP concentrations to the incubation medium under both basal and stimulating conditions. ${ }^{45} \mathrm{Ca}^{2+}$ uptake values (mean $\pm \mathrm{SEM} ; \mathrm{n}=3$ ) are expressed in $\mathrm{dpm} / 5 \times 10^{5}$ cells/12-min incubation. 
stimulate but inhibited (up to 20\%) the uptake of $\mathrm{Ca}^{2+}$ ions measured in these assays.

Determination of total ${ }^{45} \mathrm{Ca}^{2+}$ uptake as conducted above does not distinguish between incorporation into pericellular sites and increase in intracellular calcium. To measure the latter, we have preloaded NG108-15 cells with the bioluminescent calcium probe aequorin (Johnson et al., 1985; Kornecki et al., 1987). Using this technique, we have found that addition of ATP $(0.5 \mathrm{mM})$ to the extracellular medium induced a three- to fourfold increase in intracellular ionized calcium, as shown in Fig. 1. These results were verified by using the biofluorescent calcium probe Quin-2 in experiments carried out with NG108-15 cells and with cells of the cholinergic neuroblastoma clone N1E-115. Figure 2 demonstrates that in Quin-2-loaded N1E-115 cells, addition of ATP to the extracellular medium induced an increase in cytoplasmic free calcium ions $\left(\left[\mathrm{Ca}^{2+}\right]_{\mathrm{i}}\right)$. Maximal effects (threefold increase) were obtained with $1 \mathrm{~m} M$ extracellular ATP, and at higher concentrations (up to $3 \mathrm{mM}$ ) about the same increase was observed. Neither aequorin nor Quin-2 signals were induced by ATP when the cells were assayed in calcium-free media (supplemented with EGTA).

To determine whether extracellular ATP elicits a cyclic GMP response in neural cells, the intracellular GTP pools of N1E-115 cells were labeled by preincubation with $\left[{ }^{3} \mathrm{H}\right]$ guanosine. Addition of ATP caused a concentration-dependent increase in $\left[{ }^{3} \mathrm{H}\right]$ cyclic GMP production (Fig. 2). When measured as a function of incubation time, $\left[{ }^{3} \mathrm{H}\right]$ cyclic GMP values peaked within 1-2 min after ATP addition, and then declined at about half the rate observed for the initial net rise (Fig. 3). Thus, extracellular ATP can induce

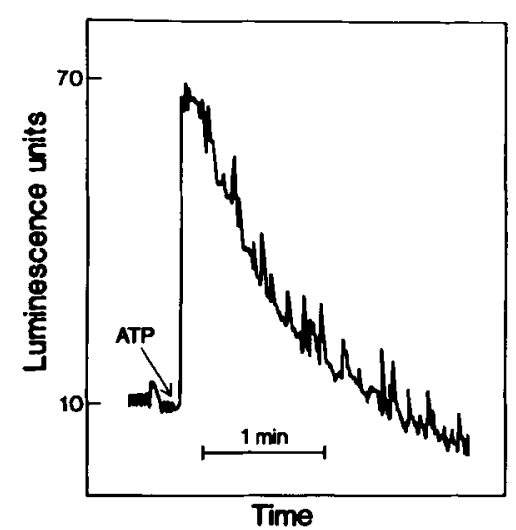

FIG. 1. ATP-induced increase of intracellular free $\mathrm{Ca}^{2+}$ in aequorin-preloaded NG108-15 cells. Cells were grown, harvested, and loaded with aequorin as described in Experimental Procedures. Chemiluminescence was measured with a PICA instrument (Chrono-Log, PA, U.S.A.), induced by injection (at the arrow) of ATP (final concentration $450 \mu M$ ) to a cuvette containing $10^{8}$ colls/ml.

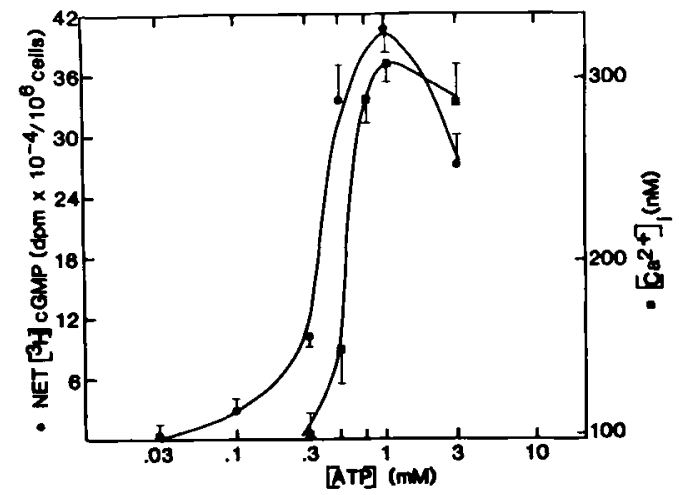

FIG. 2. Effects of increasing concentrations of extracellular ATP on intracellular free $\mathrm{Ca}^{2+}\left(\left[\mathrm{Ca}^{2+}\right]_{1}\right)$ and net $\left[{ }^{3} \mathrm{H}\right]$ cyclic GMP formation in N1E-115 cells. For these measurements cells were preloaded with Quin-2-AM or preincubated with $\left[{ }^{3} \mathrm{H}\right]$ guanosine as described in Experimental Procedures, and the assays carried out in resuspended, washed cells in the presence or absence of extracellular ATP, added to the reaction medium at the final concentrations indicated in the figure. Data shown are means ( \pm SEM) of triplicate determinations from a representative experiment. Similar results were obtained in three separate experiments. Resting $\left[\mathrm{Ca}^{2+}\right]$ in N1E-115 cells was typically $100-120 \mathrm{nM}$ and none of the experimental manipulations decreased $\left[\mathrm{Ca}^{2+}\right]_{i}$ below resting levels.

the production of a pulse of cyclic GMP from intracellular GTP in neural cells.

A novel signal transduction system investigated most intensively in recent years involves increased turnover of inositol-containing lipids (Berridge, 1981; Nishizuka, 1986). To measure the effects of ATP on this system, intact N1E-115 cells were prelabeled for $60 \mathrm{~min}$ with $m y a-\left[2-{ }^{3} \mathrm{H}\right]$ inositol and the total amount of labeled IP formed during a 30-min stimulation period in the presence of $\mathrm{Li}^{+}$was then determined. The addition of ATP $(1 \mathrm{mM})$ resulted in a 15-fold increase of $\left[{ }^{3} \mathrm{H}\right] \mathrm{IP}$ accumulation over the values ob-

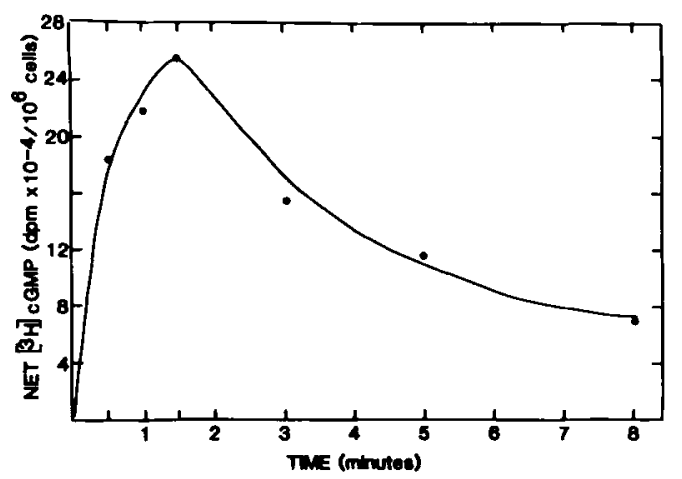

FIG. 3. Time course of net $\left[{ }^{3} \mathrm{H}\right]$ cyclic GMP formation in N1E-115 cells, induced by $1 \mathrm{mM}$ ATP added to the extracellular medium and followed by measurements conducted as detailed in Experimental Procedures, and in the legend to Fig. 2. 
tained under basal conditions (Table 2). Over $90 \%$ of the ATP-induced increase in $\left[{ }^{3} \mathrm{H}\right] \mathrm{IP}$ formation could be prevented by including the inorganic calcium blocker $\mathrm{LaCl}_{3}$ in the reaction medium (Table 2).

The stimulation of adenylate cyclase activity in NG108-15 neural cells by prostaglandins has been extensively studied by various techniques (Hamprecht et al., 1985). In our studies, it was determined that under basal conditions, $10^{6}$ cells generate a mean of $0.18 \pm 0.02$ pmol of $\left[{ }^{3} \mathrm{H}\right]$ cyclic AMP during a 10 -min incubation period. In the presence of $0.5 \mu \mathrm{M}$ prostaglandin $\mathrm{E}_{1}\left(\mathrm{PGE}_{1}\right)$, this value increased to 2.46 $\pm 0.2 \mathrm{pmol}$ of $\left[{ }^{3} \mathrm{H}\right]$ cyclic $\mathrm{AMP} / 10^{6}$ cells $/ 10 \mathrm{~min}(\mathrm{n}$ $=3 ; \mathrm{p}<0.005$ ). When $50 \mathrm{mM} \mathrm{KCl}$ (in place of $\mathrm{NaCl}$ ) were added simultaneously with $\mathrm{PGE}_{1}$, there was a $47 \pm 14 \%$ decrease in $\left[{ }^{3} \mathrm{H}\right]$ cyclic AMP formation compared to its production under nondepolarizing conditions, suggesting that $\mathrm{Ca}^{2+}$ influx decreases the responsiveness of adenylate cyclase to stimulation by $\mathrm{PGE}_{1}$. As expected from this finding, when taken together with the results presented in Table 1 and Fig. 1, similar effects were exerted by extracellular ATP. In the assays summarized in Table 3, 0.5 $\mu M$ PGE $_{1}$ caused a 24-fold increase in $\left[{ }^{3} \mathrm{H}\right]$ cyclic AMP generation, whereas only an 8.3-fold increase occurred when $0.5 \mathrm{~m} M$ ATP was added to the reaction medium. This change involved an increase in basal activity, as well as a decrease in the stimulation by $\mathrm{PGE}_{1}$. Also the inhibition of cyclic AMP formation by Met-enkephalin $(10 \mu M)$ declined somewhat in the presence of extracellular ATP, but not as greatly as the decrease in stimulation by $\mathrm{PGE}_{1}$ (Table 3 ). The mean concentration of extracellular ATP required to produce half-maximal decrease in the stimulation of cyclic AMP generation by $\mathrm{PGE}_{1}$ was found to be $510 \mu M$.

We have reported recently that NG108-15 cells exhibit endogenous ectoprotein kinase activity that phosphorylates surface proteins when the cells are incubated with extracellular ATP (Ehrlich et al., $1986 a, b)$. Such assays were carried out in the present study under conditions identical to those used for measuring $\mathrm{Ca}^{2+}$ uptake, except that $\left[\gamma^{-}{ }^{32} \mathrm{P}\right] \mathrm{ATP}$ was added to the medium instead of radiolabeled cal-

TABLE 2. Effects of extracellular ATP on accumulation of $\sum^{3} H \mid I P$

\begin{tabular}{lrc}
\hline Incubation conditions & {$\left[{ }^{3} \mathrm{H}\right] \mathrm{IP}$ accumulation } & Net response \\
\hline Basal & $532 \pm 163 \quad(\mathrm{n}=6)$ & $-\overline{-}$ \\
ATP $(1 \mathrm{mM})$ & $8,100 \pm 1,080(\mathrm{n}=6)$ & 15.2 -fold \\
$\begin{array}{l}\text { ATP }(1 \mathrm{~m} M) \\
\quad \mathrm{LaCl}_{3}(1 \mathrm{mM})\end{array}$ & $927 \pm 481 \quad(\mathrm{n}=5)$ & 1.7 -fold \\
\hline
\end{tabular}

NIE-115 cells were preincubated with $m v a-\left[2 \cdot{ }^{3} \mathrm{H}\right]$ inositol for 60 min and then incubated in the presence of $\mathrm{Li}^{+}$for $30 \mathrm{~min}$ with or without adding ATP to the extracellular medium. Data are the means \pm SEM in dpm of total $\left[{ }^{3} \mathrm{H}\right] \mathrm{IP}$ for the number of experiments shown above. Values of the results obtained with addition of ATP are for net increase over basal conditions.
TABLE 3. Effects of extracellular ATP on accumulation of $\left[{ }^{3} \mathrm{H}\right]$ cyclic $A M P$

\begin{tabular}{lcc}
\hline & \multicolumn{2}{c}{$\left[{ }^{3} \mathrm{H}\right]$ Cyclic AMP formed } \\
\cline { 2 - 3 } Incubation conditions & -ATP & +ATP \\
\hline Basal & $0.50 \pm 0.02$ & $0.76 \pm 0.02$ \\
PGE $_{1}(0.5 \mu M)$ & $12.0 \pm 0.59$ & $6.31 \pm 0.33$ \\
Met-enkephalin $(10 \mu M)_{\text {PGE }_{1}+\text { Met-enkephalin }}$ & $0.21 \pm 0.01$ & $0.42 \pm 0.02$ \\
\hline
\end{tabular}

NG108- 15 cells were prelabeled with $\left[{ }^{3} \mathrm{H}\right]$ adenine and then reincubated under the conditions indicated above in the presence and absence of $0.5 \mathrm{mM}$ ATP, added to the extracellular medium. Values are means \pm SEM $(n=3)$ of pmol $\left[{ }^{3} \mathrm{H}\right]$ cyclic AMP formed/mg protein/10-min incubation.

cium. The incorporation of ${ }^{32} \mathrm{P}$-phosphate into cellular proteins measured under these conditions as a function of ATP concentration is shown in Fig. 4. Lineweaver-Burk analysis of the data (inset in Fig. 4; $r=0.98$ ) revealed that in the concentration range of 0.1-1.0 mM ATP, this activity has a $V_{\max }$ of 12.0 pmol $\mathrm{PO}_{4} / 10^{5}$ cells $/ \mathrm{min}$ and a $K_{\mathrm{m}}$ of $525 \mu M$ ATP.

\section{DISCUSSION}

The main finding of the present study is that extracellular ATP, applied at concentrations above 100 $\mu M$, induces a significant increase in the uptake of $\mathrm{Ca}^{2+}$ ions into neural cells, and this increase is associated with elevated levels of intracellular free $\mathrm{Ca}^{2+}$. The increase in $\mathrm{Ca}^{2+}$ uptake induced by extracellular ATP was found to be additive with that produced by $\mathrm{K}^{+}$depolarization. These results suggest that the mechanism underlying the ATP-induced $\mathrm{Ca}^{2+}$ up-

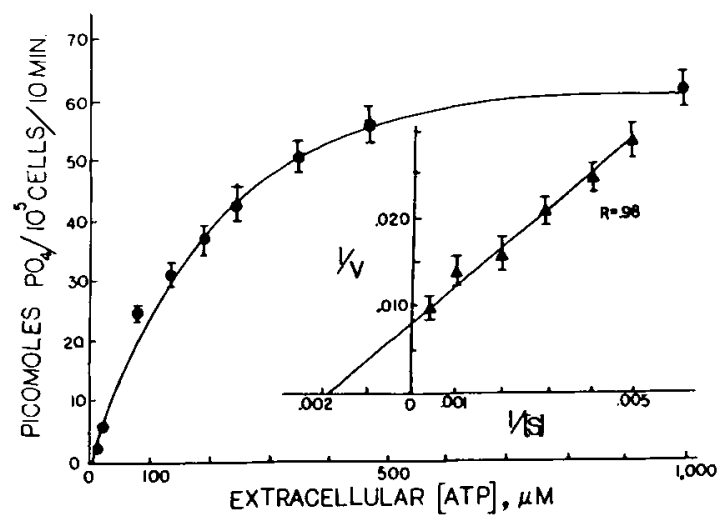

FIG. 4. Protein phosphorylation by increasing concentrations of ATP added to the extracellular medium of NG108-15 cells. After harvest and washing cells were incubated at $37^{\circ} \mathrm{C}$ in a buffer identical to that used for measuring $\mathrm{Ca}^{2+}$ uptake (Table 1), except that $\left[\gamma \cdot{ }^{32} \mathrm{P}\right]$ ATP $(10 \mu \mathrm{Ci} /$ tube) was added instead of radiolabeled calcium. ${ }^{32} \mathrm{P}$ incorporation into proteins was measured and quantitated (means $\pm \operatorname{SEM} ; n=3$ ) as detailed in Experimental Procedures. Inset: Lineweaver-Burk analysis of the data. 
take observed here may be different from those operating during routine transmission.

In addition to the increase in the uptake of $\mathrm{Ca}^{2+}$ ions induced in neural cells by extracellular ATP in the concentration range of $0.1-1.0 \mathrm{~m} M$, the present study has revealed that such stimulation brings about significant alterations in the metabolism of cyclic nucleotides and phosphoinositides. These changes are, in all likelihood, secondary to the ATP-induced increase in the intracellular level of free $\mathrm{Ca}^{2+}$ observed in these cells. Snider et al. (1984) reported that elevation of cyclic GMP levels in N1E-115 cells is mediated by activation of phospholipase $\mathrm{A}_{2}, \mathrm{a} \mathrm{Ca}^{2+}$ stimulated enzyme, and formation of arachidonic acid metabolites. The results depicted in Fig. 2 may involve similar mechanisms. The ATP-induced increase in basal adenylate cyclase activity reported here may be mediated through activation of the calmodulin-dependent enzyme by $\mathrm{Ca}^{2+}$ ions, and an excessive increase in the levels of free $\mathrm{Ca}^{2+}$ is also known to diminish the responsiveness of the cyclic AMP generating system to receptor stimulation (reviewed by Ehrlich, 1984), as seen here with PGE (Table 3). The inhibition of the response of the phosphoinositide system to extracellular ATP by $\mathrm{La}^{3+}$ (Table 2) also suggests mediation by $\mathrm{Ca}^{2+}$ uptake. Although these results do not provide direct evidence for the mechanism(s) involved, they demonstrate for the first time that extracellular ATP has significant modulatory effects on each of the principal signal transduction systems operating in neuronal communication.

The activation of signal transduction systems is usually associated with stimulus-response coupling and the production of transient, short-lived changes in neuronal function (reviewed by Nestler and Greengard, 1983). In addition, several studies have demonstrated that activity of the same signal transduction systems plays a role also in processes that initiate the production of alterations that persist for long periods, and underlie synaptic plasticity. The induction of such changes, however, requires intense and repetitive stimulation (Kandel and Schwartz, 1982; Alkon et al., 1982; Alkon, 1984; Lynch and Baudry, 1984; Ehrlich, 1984; Routtenberg, 1986). One of the molecular events that take place at the synapse during intense, repetitive stimulation would be the accumulation of extracellular ATP to levels far greater than those produced during routine transmission. Based on electrophysiological measurements and consideration of the synaptic cleft volume, Silinsky $(1975,1984)$ has estimated that the concentration of extracellular ATP coreleased with a single quantum of acetylcholine would be in the low micromolar range, whereas tetanic stimulation is required to produce extracellular ATP at concentrations above $0.1 \mathrm{~m} M$. Lynch et al. (1983) have presented evidence that repetitive stimulation produces in neurons exaggerated calcium levels that play an important role in initiating the chain of molecular events leading to LTP. The present study has provided findings indicating that extracellular ATP at concentrations that can be produced by repetitive stimulation (but not during routine transmission) elicit unique responses in neural cells, which are associated with increased $\mathrm{Ca}^{2+}$ uptake. Based on all these considerations, we propose that secreted ATP should be an important target in studies aiming to determine the nature of the unique signals responsible for the induction of longterm synaptic changes by tetanic stimulation.

Previous studies in our laboratory have provided evidence that neural cells have an ectoprotein kinase activity that utilizes extracellular ATP as a cosubstrate in the phosphorylation of surface proteins (Ehrlich et al., 1986a,b). In the present study, we have found that when surface protein phosphorylation in NG108-15 neural cells is measured in the ATP concentration range of 0.1-1.0 $\mathrm{m} M$, it has a $K_{\mathrm{m}}$ for ATP that is almost identical to the $K_{0.5}$ values for the ATP-induced increase in $\mathrm{Ca}^{2+}$ uptake and the decreased $\mathrm{PGE}_{1}$-stimulated cyclic AMP generation in these cells. This correlation does not prove that there are causal interactions between these activities, but provides the data basis for further studies designed to examine the role of ectoprotein kinase in the regulation of neuronal responsiveness. In preliminary experiments, we have begun using two approaches to this investigation. In NG108-15 cells preincubated with ATP- $\gamma-S$, decreased responsiveness of the cyclic AMP generating system to PGE $_{1}$ was observed although the cells were extensively washed between the pre- and reincubation phases of the assay. The capacity of ATP- $\gamma-S$ to thiophosphorylate neuronal membrane proteins irreversibly (Whittemore et al., 1984) may play a role in the observed effect. Using another approach, addition of phosphorylase kinase to the assay medium was found to increase the stimulation of $\mathrm{Ca}^{2+}$ uptake induced in NG108-15 cells by extracellular ATP. The identification of the surface phosphoproteins involved can now be pursued.

In conclusion, we have demonstrated that extracellular ATP can exert potent and unique effects on several signal transduction systems operating in neural cells. Since these effects are induced by ATP concentrations expected to be present in the synaptic cleft after repetitive stimulation but not during routine transmission, it will be of importance to determine whether secreted ATP provides a signal that initiates a chain of events leading to long-term alterations induced by tetanic stimulation under certain pathophysiological conditions, such as epileptogenic seizures, and in physiological processes underlying synaptic plasticity.

Acknowledgment: We are grateful to Drs. M. Hacker and E. Hendley for helpful discussions and to Ms. Sandi Bonn for typing the manuscript. These studies have been supported by Grant 84-0331 from the USAFOSR (Y.H.E.) and by NIH Grant NS 20920 (R.M.S.). 


\section{REFERENCES}

Alkon D. L. (1984) Calcium-mediated reduction of ionic currents: a biophysical memory trace. Science 226, 1037-1045.

Alkon D. L., Lederhendler I., and Shoukimas J. J. (1982) Primary changes of membrane currents during retention of associative learning. Science 215, 639-695.

Arslan P., Di Virgilio F., Beltrame M., Tsien R. Y., and Pozzan T. (1985) Cytosolic $\mathrm{Ca}^{2+}$ homeostasis in Ehrlich and Yoshida carcinomas. A new, membrane-permeant chelator of heavy metals reveals that these ascites tumor cell lines have normal cytosolic free $\mathrm{Ca}^{2+}$. J. Biol. Chem. 260, 2719-2727.

Berridge M. J. (1981) Phosphatidylinositol hydrolysis: a multifunctional transducing mechanism. Mol. Cell. Endocrinol. 24, $115-140$.

Burnstock G. (1972) Purinergic nerves. Pharmacol. Rev. 24, 509-581.

Burnstock G. (1975) Purinergic transmission, In Handbook of Psychopharmacology, Vol. 5 (Iverson L. L., Iverson S. D., and Snyder S. H., eds), pp. 131-194. Plenum Press, New York.

Burnstock G. (1981) Neurotransmitters and trophic factors in the autonomic nervous system. J. Physiol. 313, 1-35.

Castel M., Gainer H., and Pellman H. D. (1984) Neuronal secretory systems. Int. Rev. Cytol. 88, 303-359.

Daly J. W., Kuroda Y., Phillis J. W., Shimizu H., and Ui M., eds. (1983) Physiology and Pharmacology of Adenosine Derivatives. Raven Press, New York.

Ehrlich Y. H. (1984) Protein phosphorylation: role in the function, regulation and adaptation of neural receptors, in Handbook of Neurochemistry. Vol. 6 (Lajtha A., Ed), pp. 541-574. Plenum Press, New York.

Ehrlich Y. H., Davis T., Bock E., Kornecki E., and Lenox R. H. (1986a) Ecto protein kinase activity on the external surface of intact neural cells. Nature 320, 67-69.

Ehrlich Y. H., Garfield M. G., Davis T. B., Kornecki E., Chaffee J. E., and Lenox R. H. (1986b) Extracellular protein phosphorylation systems in the regulation of neuronal function, in Progress in Brain Research, Vol. 69: Phosphoproteins in Neuronal Function. (Gispen W. H. and Routtenberg A., eds), pp. 197-208. Elsevier, Holland.

Fisher S. K., Figueiredo J. C., and Bartus R. T. (1984) Differential stimulation of inositol phospholipid turnover in brain by analogs of oxotremorine. J. Neurochem. 43, 1171-1179.

Gordon J. L. (1986) Extracellular ATP: effects, sources and fate. Biochem. J. 233, 309-319.

Hamprecht B., Glaser T., Reiser G., Bayer E., and Propst F. (1985) Culture and characteristics of hormone-responsive neuroblastoma $\times$ glioma hybrid cells. Methods Enzymol. 109, 316-341.

Holton F. A. and Holton P. (1954) The capillary dilator substances in dry powders of spinal roots: a possible role of ATP in chemical transmission from nerve endings. J. Physiol. (Lond.) 126 , 124-140.

Hume R. I. and Honig M. G. (1986) Excitatory action of ATP on embryonic chick muscle. J. Neurosci. 6, 681-690.

Johnson P. C., Ware J. A., Cliveden P. B., Smith M., Dvorak A. M., and Salzman E. W. (1985) Measurement of ionized calcium in blood platelets with the photoprotein aequorin. Comparison with Quin 2. J. Biol. Chem. 260, 2069-2076.

Kandel E. R. and Schwartz J. H. (1982) Molecular biology of learning: modulation of transmitter release. Science 218, 433-443.

Kornecki E., Lenox R. H., Hardwick D. H., and Ehrlich Y. H (1987) A role for platelet activating factor (PAF) in neuronal function: specific inhibition of platelet activation by triazolobenzodiazepines and interactions of PAF with cultured neural cells, in New Horizons in Platelet Activating Factor Research, (Lee M. L. and Winslow C. M., eds), pp. 285-292, John Wiley Sons, Chichester, England.

Lenox R. H., Ellis J., Van Riper D., and Ehrlich Y. H. (1985)
$\alpha_{2}$-Adrenergic receptor-mediated regulation of adenylate cyclase in the intact human platelet: Evidence for a receptor reserve. Mol. Pharmacol. 27, 1-7.

Lynch G. and Baudry M. (1984) The biochemistry of memory: a new and specific hypothesis. Science 224, 1057-1063.

Lynch G., Larson J., Kelso S., Barrionuevo G., and Schottler F. (1983) Intracellular injections of EGTA block induction of hippocampal long-term potentiation. Nature 305, 719-721.

Mastro A. M. and Rozengurt E. (1976) Endogenous protein kinase in outer plasma membrane of cultured $3 \mathrm{~T} 3$ cells. J. Biol. Chem. 251, 7899-7906.

Nestler E. D. and Greengard P. (1983) Protein phosphorylation in the brain. Nature 305, 583-588.

Nirenberg M., Wilson S., Higashida H., Rotter A., Krueger K., Busis N., Ray R., Kenimer J. G., and Adler M. (1983) Modulation of synapse formation by cyclic adenosine monophosphate. Science 221, 331-338.

Nishizuka Y. (1986) Studies and perspectives of protein kinase C. Science 233, 305-312.

Richardson P. J. and Brown S. J. (1987) ATP release from affinitypurified rat cholinergic nerve terminals. $J$. Neurochem. 48, 622-630.

Richelson E. (1979) The use of cultured cells in neurobiological studies, in International Review of Biochemistry, Physiological and Pharmacological Biochemistry, Vol. 26 (Tipton K. F., ed), pp. 81-120. University Park Press, Baltimore.

Routtenberg A. (1986) Synaptic plasticity and protein kinase C, in Progress in Brain Research, Vol. 69 (Gispen W. H. and Routtenberg A., eds), pp. 211-234. Elsevier, Amsterdam.

Silinsky E. M. (1975) On the association between transmitter secretion and the release of adenine nucleotides from mammalian motor nerve endings. J. Physiol. 247, 145-162.

Silinsky E. M. (1984) On the mechanism by which adenosine receptor activation inhibits the release of acetylcholine from motor nerve endings. J. Physiol. 346, 243-256.

Silinsky E. M. and Hubbard J. I. (1973) Release of ATP from rat motor nerve terminals. Nature 243, 404-405.

Silinsky E. M. and Ginsborg B. L. (1983) Inhibition of acetycholine release from preganglionic frog nerves by ATP but not adenosine. Nature 305, 327-328.

Snider R. M. and Richelson E. (1984) Bradykinin receptor-mediated cyclic GMP formation in a nerve cell population (murine neuroblastoma clone NIE-115). J. Neurochem. 43, 1749-1754.

Snider R. M., McKinney M., Forray C., and Richelson E. (1984) Neurotransmitter receptors mediate cyclic GMP formation by involvement of phopholipase $A_{2}$ and arachidonic acid metabolites. Proc. Nall. Acad. Sci. USA 81, 3905-3909.

Stone T. W. (1981) Physiological roles for adenosine and ATP in the nervous system. Neuroscience 6, 523-555.

Teyler T. J. and Discenna P. (1984) Long-term potentiation as a candidate mnemonic device. Brain Res. Rev. 7, 15-28.

Tsien R. Y., Pozzan T, and Rink T. J. (1982) Calcium homeostasis in intact lymphocytes: cytoplasmic free calcium monitored with a new, intracellularly trapped fluorescent indicator. $J$. Cell Biol. 94, 325-334.

Whittemore S. R., Graber S. G., Lenox R. H., Hendley E. D., and Ehrlich Y. H. (1984) Activation of adenylate cyclase by preincubation of rat cerebral-cortical membranes under phosphorylating conditions: role of ATP, GTP, and divalent cations. $J$. Neurochem. 42, 1685-1696.

Williams M. (1987) Purine receptors in mammalian tissues. Annu. Rev. Pharmacol. Toxicol. 27, 315-345.

Winkler $H$. (1976) The composition of adrenal chromaffin granules: an assessment of controversial results. Neuroscience 1, 65-80.

Zimmerman H. (1978) Turnover of adenine nucleotides in cholinergic synaptic vesicles of the Torpedo electric organ. Neuroscience 3, 827-836. 